\title{
Incorporation of Socio-Cultural Values in Damage Assessment Valuations of Contaminated Lands in the Niger Delta
}

\author{
Victor A. Akujuru * and Les Ruddock \\ School of The Built Environment, University of Salford, Salford, M4 4WT, UK; \\ E-Mail: 1.ruddock@salford.ac.uk \\ * Author to whom correspondence should be addressed; E-Mail: v.akujuru@edu.salford.ac.uk; \\ Tel.: +44-777-892-3597.
}

Received: 25 February 2014; in revised form: 23 June 2014 / Accepted: 23 June 2014 /

Published: 9 July 2014

\begin{abstract}
Damages on contaminated land have been mostly assessed for developments subsisting on the land, neglecting the goods and services derived from the land which possess only socio-cultural values. This paper aims to ascertain the importance of socio-cultural values in the total economic value of contaminated land, drawing from the experience of a coastal community oil spillage in the Niger Delta. The paper examines what constitutes a valuable interest on contaminated land and how socio-cultural factors are valued in the damage assessment process. After reviewing the literature and decided cases, a questionnaire survey was conducted and a sample valuation report was analysed. It is concluded that there exists a socio-cultural interest on contaminated land which professional valuers do not reflect in damage assessment claims. It is recommended that any comprehensive damage assessment requires the incorporation of socio-cultural values in the valuations.
\end{abstract}

Keywords: damages; valuations; socio-cultural values; total economic values

\section{Introduction}

Many rural communities depend on nature to varying degrees for their wellbeing. Such dependence may be for food, raw materials for many uses such as building, basket weaving, carvings, and other uses, traditional medicines to satisfy their subsistence needs, and religious and cultural beliefs. Most of the goods gathered from nature being social and cultural are akin to public goods and are freely 
gathered by members of the communities without any person laying claim to ownership. Since these goods occur on land within the Niger Delta, land owners have always claimed loss of income when they are destroyed by any contamination. The real estate valuation professional is frequently consulted to advise on the damages suffered in the wake of a contamination incident like an oil spill, but it has been argued that the skills of the real estate valuer is specific, and subject to significant legal constraint, and should not be considered appropriate for the determination of other forms of value besides the core real estate [1]. Though the law in Nigeria recognises the real estate valuer as the only professional who can advise on the value of property of any description in Nigeria as contained in the relevant law registering Valuers (Cap E.13, LFN 2007) [2], professional valuers fail to incorporate social and cultural values in their valuation, when asked to determine the loss in value due to contamination. This paper seeks to explore the incorporation of social and cultural values into the determination of the total economic value of contaminated wetlands in the Niger Delta. It examines the types of goods that are prevalent in the region and after reviewing some literature, conducts a survey within a coastal community that suffered an oil spillage with a questionnaire and a contingent survey. The findings indicate that to determine the total economic value of a contaminated coastal land, the social and cultural values of the goods existing in the area as perceived by the inhabitants of the land must be incorporated into the valuation, if the affected households are to consider the resultant damage estimate to be adequate. This is in line with the assertion by Redford [3] that the American Comprehensive Environment Response, Compensation and Liability Act (CERCLA) 1980 established liability for publicly-owned natural resources whose values are non-market derivatives and need to be determined by novel methods of ascertaining values in the absence of an obvious market.

\section{Geographic Location}

The Niger Delta with an estimated area of about $70,000 \mathrm{~km}^{2}$ is one of the world's largest deltas. It is located in the central part of Southern Nigeria between above latitude $5^{\circ} 33^{\prime} 49^{\prime \prime} \mathrm{N}$ and $6^{\circ} 31^{\prime} 38^{\prime \prime} \mathrm{E}$ in the north. Its western boundary is given as Benin $5^{\circ} 44^{\prime} 11^{\prime \prime} \mathrm{N}$ and $5^{\circ} 03^{\prime} 49^{\prime \prime} \mathrm{E}$ and its eastern boundary is Imo River $4^{\circ} 27^{\prime} 16^{\prime \prime} \mathrm{N}$ and $7^{\circ} 35^{\prime} 27^{\prime \prime} \mathrm{E}$.

It contains the world's third largest mangrove forest, the most extensive freshwater swamp forest in West and Central Africa and most of Nigeria's primary forests. The region, situated in the southern part of Nigeria, is bordered in the east by the Republic of Cameroun and, in the south, by the Atlantic Ocean. Within Nigeria, the region is defined both geographically and politically, the latter description being for revenue sharing purposes. The geographic Niger Delta includes the littoral States of Rivers, Bayelsa, Delta Cross River and Akwa Ibom and has an area of about 67,284 square kilometres with a combined population of 16,331,000 persons. The political Niger Delta includes these and, in addition, Abia, Edo, Imo, and Ondo states, with a total area of 112,110 square kilometres of land as at 2006. The region represents about $12 \%$ of Nigeria's total surface area (NDDC [4]). Figure 1, shows the States now known as the political Niger Delta States by the National Space Research and Development Agency of Nigeria (NASRDA) [5].

The area consists of a vast coastal plain spanning approximately $853 \mathrm{~km}$ facing the Atlantic Ocean endowed with immense natural resources especially hydrocarbon deposits. It is estimated to have about 37.2 billion barrels of proven oil and 5.153 trillion cubic feet of gas reserves as at the end of 
2012 [6]. The crude oil production and export of the region accounts for about $95 \%$ of the nation's total export earnings and more than $75 \%$ of Federal Government revenue in 2011, and places the country as the largest oil producer in Africa and the world's ninth highest producer of crude oil and the 10th highest gas producer, according to the International Monetary Fund (IMF). The region has a lot of gas reserves, which when sufficiently harnessed, could yield income for an excess of crude oil incomes. There are about 606 oil fields in the Niger Delta, of which 360 are on-shore and 246 are offshore (Nwilo and Badejo, [7]). Most of the new oil fields are deep water fields developed and being developed offshore. Within the Niger Delta area, there are over 21,000 kilometres of moderate-to-large (152 mm-1219 mm diameters) oil pipelines; about 5284 oil wells drilled and 527 flow stations for crude oil processing, with more than $7000 \mathrm{~km}$ of oil and gas pipelines traversing the entire area, and seven export terminals (DPR, [8]). The region houses key industries with three refineries, two petrochemical plants, one liquefied natural gas, a major steel plant and three gas-faced electric power generating stations.

Figure 1. Map of the political Niger Delta. Adapted image from NASRDA [5].

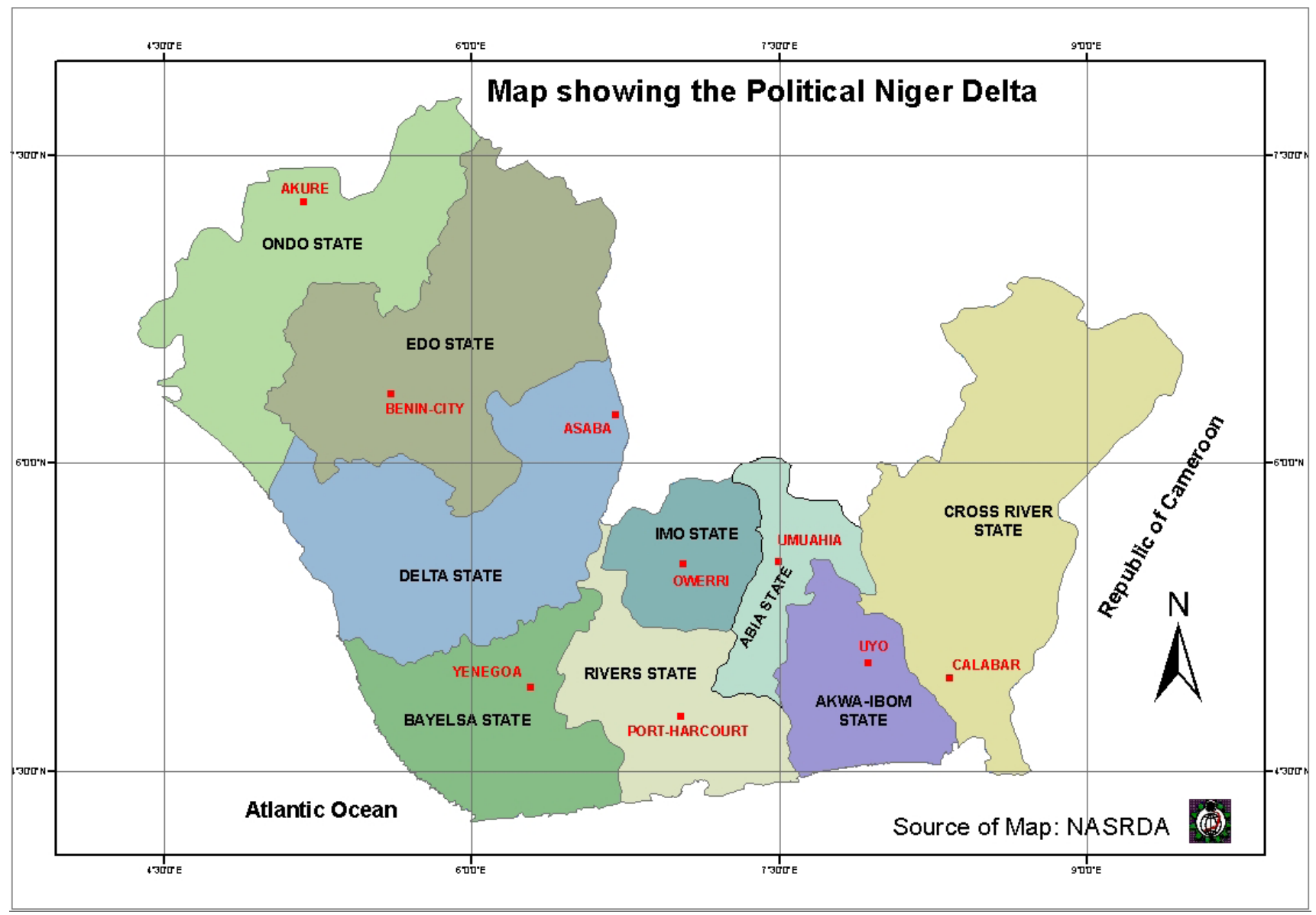

Official statistics indicate that, between 1976 and 1996 a total of 4647 incidents resulted in the spill of approximately 2,369,470 barrels of oil into the environment [9]. Babawale [10] reported other major spills to include the GOCON's Escravos spill in 1978 involving about 300,000 barrels; SPDC's Forcados Terminal tank failure in 1978 involving about 580,000 barrels; and the Texaco blow out at Funiwa-5 offshore station in 1980 involving about 400,000 barrels. Others are those of the Abudu pipe 
line in 1982 involving about 18,818 barrels; the Jesse Fire Incident which claimed about a thousand lives and the Idoho Oil Spill of January 1998 involving about 40,000 barrels. Nigeria's largest spill was an offshore well blow-out in January 1980 when an estimated 200,000 barrels of oil (8.4 million US gallons) spilled into the Atlantic Ocean from an oil industry facility which damaged 340 ha of mangrove.

The region is endowed with both renewable and non-renewable natural resources. The major non-renewable resources include fossil fuels, crude oil and natural gas and construction materials such as gravel, sand, clay and earth. Sand is obtained from both land and river beds.

Renewable resources include water resources, timber, pole wood, fuel wood, edible vegetables, fruits, nuts and seeds; medicinal plants, palm wine and other palm products; fibres and tannin, bamboo and grasses; as well as wildlife and a rich aquatic life yielding abundant resources of shell and fin fish and crustacean. There is an interface between environment and development which is of global concern. The exploitation of resources or raw materials for use in economic activities, agro-processing and industrial activities impact negatively on the environment of the Niger Delta.

\section{Materials and Methods}

The Land Law in Nigeria is the Land Use Act 1978 known as CAP. L5, LFN, 2004 [11]. This law now vests all land in the territory of each state (except land vested in Federal Government or its agencies) exclusively in the Governor of the State. The Governor holds such land in trust for the population and administers it on behalf and for all Nigerians. The Governor is responsible for the control and management of land in urban areas; similar powers with respect to non-urban areas are conferred to Local Governments. Each Governor is assisted by a Land Use and Allocation Committee for the management of urban lands, while each local government is assisted by a land advisory Committee for the management of rural lands. The Governor has the power to grant land to any person with occupancy statutory rights for all purposes. It is lawful for local governments to grant any person with customary rights of occupancy for agricultural, residential and other purposes. Since the enactment of the LUA, the traditional authorities of the Niger Delta communities have lost their rights and powers and are no longer able to effectively manage complaints since Cap L5 2(1) provides that "as from the commencement of this Act"-

a. "All land in urban areas shall be under the control and management of the governor of each state:

b. All other land shall, subject to this Act, be under the control and management of the local government within the area of jurisdiction of which the land is situated."

Most land in the Niger Delta falls under the management of the local government since they are outside the designated urban areas and are mostly rural in nature. The major occupation of the rural dwellers is agriculture for subsistence living. Being rural, the inhabitants are the main custodians of the culture of the different ethnic nationalities that inhabit the region. Uchendu [12] points out that land in Southern Nigeria, had a "folk image" as it is not a mere piece of earth but a piece of earth that produced a sense of pride and attachment that was out of all proportion to the mere two hectares a family might hold, and land embodies the spirit of the Earth deity - a revered mother who blesses land with her bountiful gifts. Land is also the burial place for the ancestors, those invisible 
father-figures who bequeathed their land to a "vast family" which includes the dead, the living, and the unborn. Rosa et al. [13] opined rural communities have a deep relationship to the lands they occupy not only as the basis for their economic subsistence but also as a central element of their cultural identity, social organization, and belief systems and that these same lands often provide important environmental services that depend on the labour and knowledge of the community members, as in the conservation of agricultural biodiversity. They stated that in other cases, such as regulation of the quality and quantity of water flows, human activities can have both positive and negative effects. Most rural communities rely on the natural resources to meet their basic needs, e.g., gathering non-timber forest products (NTFPs) like firewood, herbs, vegetables, snails, periwinkle, water, staking sticks, ropes, and spiritual well-being. They use these for their own consumption and earn income from their sales. The extent to which these resources are valuable depends on the cultural practices of the community in terms of control and use of the environment.

The extent of control and use of natural resources are determined to a large extent by the property rights held by the community (Rosa et al. [13]). Schlager and Ostrom (1992), (cited by Rosa et al. [13]) stated these rights to be access rights which give the right to enter into the area and enjoy non-extractive benefits like recreation, withdrawal rights which combine access and the right to extract and gather different products. There are management rights which confer the right to determine the pattern of use and exclusion rights which empower the holder to decide who can have access and extract resources. Alienation rights confer power to transfer to others.

The Niger Delta is a wetland, classified as the world's third largest wetland. Wetlands are generally divided into the three categories of marine/coastal wetlands, inland wetlands, and manmade wetlands.

Ecosystem goods and services derive their nature from the ecosystem functions which is defined by de Groot et al. [14] as the capacity of natural processes and components to provide goods and services that satisfy human needs, directly and indirectly. They stated that the functions are a subset of ecological processes and ecosystem structures and that each function is the result of the natural processes of the total ecological sub-system of which it is a part. According to them, value in economics is always associated with trade-offs and is usually measured in monetary terms but in their view, monetary measures fail though to incorporate other types of value which are critical to understanding the relationship between society and nature. They suggested alternative measures such as livelihood assessment, capabilities approaches, and vulnerability assessments for such goods where it is felt that economic valuation may not reflect their true values. In their framework, it is suggested that economic valuation methods may be (1) direct market valuation, (2) indirect market valuation, (3) contingent valuations, and group valuations. They opine that for all types of ecosystem functions, it is possible in principle to derive a monetary estimation of the human preferences for the continued availability and maintenance of the related ecosystem services and for cultural goods and services; they recommended the contingent valuation method for their valuation.

Natural processes are equally the result of complex interactions between living organisms and chemical and physical components of ecosystems. Curtis [15] defined ecosystem services as the products of the role that ecological systems play in providing sustainable environment for life support, such as clean air, clean water, food, habitat and recreational opportunities. Turner et al. [16] state that one of the most widely cited definitions is the Millennium Ecosystem Assessment [17] definition which describes ecosystem services as "the benefits that people obtain from ecosystems which include 
provisioning services like food and water, drought, land degradation, and disease, supporting services such as soil formation and nutrient cycling, and cultural services such as recreational, spiritual, religious and other nonmaterial benefits". In de Groot et al. [14] definition, ecosystem functions can be grouped into provisioning, habitat, production, and cultural/information functions. These functions are vital to the inhabitants of the Niger Delta and require being valued, especially when contaminated. Most of the goods and services derived from the region are not marketable and thus are not being valued and included in the compensation items to be paid for when contamination occurs. This is a direct consequence of the epistemological tradition of economics which has evolved from a specific socio-cultural context, which presumes that economic values are predefined, held by people as preferences and can be derived by analysis, either as stated or revealed preference methods [18]. Justifying the need for valuation, they suggested that valuation can function as a system of cultural projection which imposes a way of thinking and a form of relationship with the environment, a particular notion of property and ownership, and view of development and what constitutes human wellbeing. It can serve as a tool for self-reflection which helps people rethink their relations to the natural environment and increase knowledge about the consequences of consumption choices and behaviour for distant places and people. That valuation can work as a feedback mechanism for a society that derives its resources but has distanced itself from the environment for the consequences of its actions. Generally, valuation can highlight the value of nature to both policy makers and users of the environment. In challenging the market view of the value of ecosystem goods and services, Zografos and Kumar [18] cited Wilk and Cligget (2006) to state that economic values are not objective facts and do not reflect universal truths but rather reflect the culturally constructed realities, worldviews, mind sets and belief systems of particular societies and/or sectors of society. This means that even non-marketable services like ancestral and religious beliefs do possess value.

Contributing to the valuation of non-marketable goods like exotics, Yagha [19] stated that valuation has focused unduly on physical real estate with its attributes, neglecting the wider realm of value possessed by exotics which have a narrow market band or stock that have a dormant market. He opined that African exotic assets command a special place in the market because the continent was the cradle of civilisation and also because of the luxuriant geography and mysterious societies inhabiting it. Some of the assets are NTFPs like plants, fruits, flowers, and herbs, spices, animals and wildlife, forests, parks, and nature reserve, artefacts like totems, ornaments, shrines, and sacred places. The United Nations Food and Agricultural Organisation [20] defines NTFPs as products of biological origin other than wood derived from forests, other wooded land and trees outside forests, gathered from the wild, or produced in forest plantations, agroforestry schemes and from trees outside forests. Akanni [21] defines NTFPs as consisting of naturally grown stocks of forest resources which could be processed either for household consumption or for local and external trade by the forest users. They include a wide range of edibles and non-edibles such as fruits, seeds, leaves, nuts, bush meat, roots, tubers, fibres, resins, latex, sticks, ropes, and construction materials like bamboos and rattans and a host of others. This means that NTFPs include all natural resources form the forest besides timber. Sullivan [22] stated that tropical forests such as found in the Niger Delta, constitute about $6 \%$ of the earth's surface and contain the greatest proportion of the earth's biota and that most of the rural villages make up their incomes from NTFPs. Examples of the NTFP values are in Guyana where 8000 plant species and 1000 species of land vertebrates are found (Sizer, 1997 cited by Sullivan [22]). 
Confirming the importance of NTFPs, Hoare [23] asserted that NTFPs provide a wealth of resources for both rural and urban dwellers throughout Central Africa where they are used as food, medicines, construction materials, fuel wood, as well as resources of spiritual and cultural significance. He cautioned that the significance of forest resources for people's culture must not be overlooked as the use of many resources are closely linked with people's beliefs and identity. Earlier, Clark and Sunderland [24] had stated that in the Congo Basin, there are 400 mammal species, more than 1000 bird species, and over 10,000 plant species, of which 3000 are endemic to the region and that more than $90 \%$ of the human inhabitants of the region depend on natural resources, including agriculture and non-timber forest products, for food, medicine, income and timber. With these observed values of NTFPs, it becomes difficult to appreciate why they are not captured by valuers when assessing damages on contaminated wetlands in the Niger Delta.

Besides the NTFPs, the forest also serves in some instances as cultural properties, where families or communities perform their traditional rites as the occasion demands. The concept of cultural property first gained international prominence in 1954 when the Hague Convention first stated the need to protect the cultural heritage of all humanity. The UNESCO Recommendations of 1962 stated the need to safeguard landscapes, natural environments and those created by man, which are of cultural or aesthetic interest, or which form a natural harmonious whole [25]. Ogunba and Adegunle [26] define cultural heritage as legacies of physical artefacts and intangible attributes of a group or society that are inherited from past generations, maintained in the present and bestowed for the benefit of future generations, and that they comprise works of nature or works of man which have significant historical, cultural, social values and relevance to the host people. In most Niger Delta communities, this may be a sacred forest, tree, shrine, or totem and most families perform rituals in such places before sharing farm portions to their members, believing that, if they do not appease their ancestors there, their farm may not yield a fruitful harvest. Some of such sites have restricted entry either by females or strangers and only the "Chief Priest" enters freely to perform sacrifices therein. Most of such sites have no built structures around them thereby rendering them undefinable as buildings or huts that can be measured for valuation purposes. As Ogunba and Adegunle [26] opined, the sheer number of such sites excludes them from being listed by government as heritage sites. The value of these sites to the Niger Delta people is illustrated by the common practice of many sacred places and shrines being created along the right of way of any proposed pipeline or road route prior to assessment for compensation, once the proposed route has been defined by land surveyors. In view of the importance of NTFPs and cultural properties which possess both social and economic values, this paper contends that there is need to capture these values in any valuation assignment.

In consideration of all this, this paper accepts the composition of the total economic value (TEV) of an ecosystem, as the unit of valuation in assessing damages due to contamination. Figure 2 illustrates the composition.

From this figure, the ecosystem goods and services consists of ecological values that sustain the ecosystem, socio-cultural values which capture the perception of the inhabitants of the region about the ecosystem both in terms of what they can collect from the environment and how they perceive it. Since land customarily belongs to past, present and future generations, some of this value may be in the future, while some may refer to the cultural beliefs handed down from past generations to the present, who will in turn protect it for the present and future generations, believing that consequences await any 
defaulting custodian. The third component is the economic value which measures the economic values of those assets that are marketable like bush meat, oil palm trees and timber. Any attempt to determine the total economic value of an ecosystem like the Niger Delta wetland must incorporate these three components. The practice of assessing damages payable on contaminated wetlands only concentrates on the economic value, while neglecting the socio-cultural values in view of their passive nature and un-marketability.

Figure 2. Framework for total economic value valuation. Adapted from De Groot et al. [14].

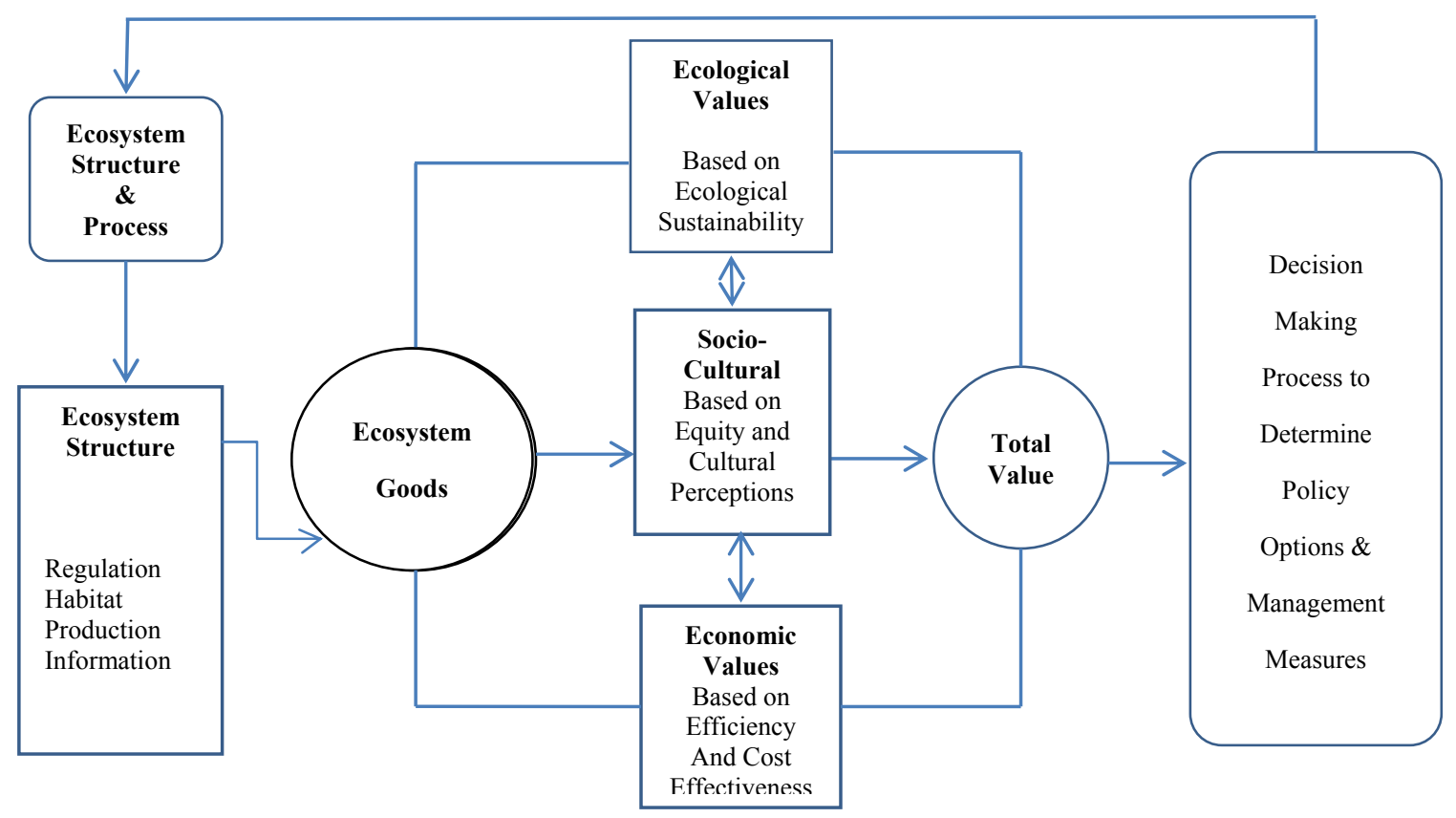

In the context of this paper, it is the determination of the composite income that should include socio-cultural values of NTFPs and shrines and totems that has been an issue with valuers. While the valuations of fish ponds and mangrove trees were easily done, the valuation of the NTFPs and the re-consecration of the shrines became contentious as no known valuation approach existed to adopt for such valuation. Professional valuers retained by the community adopted prescribed rates used by the International Oil Companies in the Niger Delta, known as OPTS (Oil Producers Trade Section) Rates. These rates did not provide for NTFPs and shrines, which is in line with the International Valuation Standards (IVSC, [27]; p. 324) provision for the valuation of cultural properties. The IVSC standard only accommodates buildings or structures, designated as historic property in line with the practice in Europe, and do not accommodate the African practice where no structure may exist, yet a forest may be regarded as sacred. The shrines pointed out by the community had no structures but were mostly trees or groups of trees. This paper contends that this community's feelings will only be assuaged if their perceived loss is captured in any attempted valuation of this passive environmental resource. Environmental damage valuation focuses on relationships over time and space between damaged resources and the behaviour and utility levels of the affected individuals (Defrancesco et al. [28]). They can be valued by any of the imputed preference methods, revealed preference methods or stated preference methods. 
Imputed Preferences Methods (IPMs), inferring values through prices or costs, is where individuals indirectly express their preferences for environmental resources. The World Bank [29] states that these methods estimate a damage on the underlying basic assumption that welfare losses linked to environmental damage are at least equal to what affected individuals pay in order to avoid the damage, restore the resource or substitute the damaged environmental goods and services. The methods included in this group are defensive expenditures, restoration costs, or substitution costs.

Revealed Preferences Methods (RPMs) infer an environmental resource value from the decisions of individuals in the market place by examining the demand for substitute or complementary goods and services linked to the environmental resources. This means that it identifies how a non-marketed good or service influences actual market for some other good or service and includes methods like market prices, travel costs, or hedonic pricing.

Stated Preferences Methods (SPMs) are also market based but rely on constructed markets, by asking people what economic value they attach to goods and services [30]. Common methods included in this group are Contingent Valuation and Choice Modelling.

Citing Garrod and Willis 1999, Defrancesco et al. [28] asserted that IPMs have low assessment costs and short estimation time but they may estimate damages inaccurately when restoration costs do not represent full replacement of lost environmental values or overstate them when restoration is inefficient. Underestimations may also occur due to lack of full appreciation of the welfare changes affecting all individuals involved and the full range of passive values. They stated that RPMs can give more accurate estimates than IPMs but they do require more data and time and thus involve high cost of use. For SPMs, they asserted that they can be used for a wider range of environmental damages and they are suitable when irreversible damages occur and passive losses are relevant. They suffer the disadvantage of being expensive both in terms of cost and time and are capable of producing unreliable estimates if not properly applied.

Socio-cultural values include use for therapeutic value, amenity value, heritage value, spiritual value and existence value. For spiritual values including inspiration though contact with nature, [31] opined that monetary valuation raises a number of issues/concerns as such values are likely to vary enormously between individuals, for instance a wilderness which some find highly valuable for its wildness may be regarded by others as being of negative value as being seen to be scary, chaotic, or dangerous, and that SPMs like the Contingent Valuation method have been used to assess spiritual values. For this study, the CVM is considered very suitable since there is no market for spiritual beliefs and no existing market prices for shrines and totems, hence it was adopted.

To determine the losses suffered from the loss of NTFPs and the desecration of the community's shrines entailed conducting a survey. The survey entailed serving a questionnaire on the families identified by the community as owning the land adjoining the coastal areas that were contaminated by the oil pollution. The aim of the survey was to ascertain the earnings from the identified NTFPs per adult member of the population. To ascertain the losses due to desecration of the shrines, a contingent survey was conducted, involving interviewing the "chief priests" of the major shrines. This is in keeping with Lusvardi [32] who stated that contingency valuation is based on opinion research surveys to determine how willing people or experts are to pay to visit or protect natural resources. 


\section{Contingent Valuation Method}

Contingent valuation is a survey-based approach and a variant of the SPMs that attempts to create a hypothetical market for a good or service by constructing a scenario in which survey respondents indicate the amount they would pay to hypothetically acquire the good or service described in the questionnaire (Mathews, [33]). The method is used for goods or services that are not marketable like recreational fishing on a public river, where the value cannot be observed from the market behaviour of buyers and sellers. In a typical CVM study, a questionnaire is used to ask respondents "How much would you be willing to pay for a change in the quantity and/or quality of a good X?". The process entails (i) deciding what change we are going to value; (ii) deciding how we are going to implement the questionnaire and the type of questionnaire to be used; (iii) design and testing the questionnaire; (iv) collecting data; and (v) statistical analysis. Some advantages of CVM are its flexibility; it is widely accepted as a method for estimating total economic value, including all types of non-use, or "passive use" values; the results are easy to analyse and describe and it is widely used. Some identified disadvantages are (i) the controversy regarding its adequacy in measuring willingness to pay (WTP); (ii) it is very expensive and time-consuming to undertake; (iii) some respondents may be unfamiliar with placing monetary values on environmental goods and services and thus may state unreliable values; (iv) respondents may deliberately express feelings to a different question than those asked; (v) responses may be related to the respondents' association of the cause and effect of the occurrence of the incident; (vi) actual decisions may differ from hypothetical decisions; (vii) suggesting a starting bid may affect the respondents' final WTP; (viii) responses may be given to bias the outcome where the respondents stand to benefit; (ix) non-response bias when those who fail to respond may have different views from those who respond; (x) non-use values are difficult to validate externally; and (xi) responses about WTP may depend on where the question is placed on the list of things being valued. Despite these disadvantages, this study accepts the CVM as the most suitable valuation method to value the damages suffered by the natives whose shrines were affected by the oil spill, just as it was used in assessing damages due to the oil pollution from the Exxon Valdez oil spill of 1989 to value loss of recreational value [33]. This method also will assuage the feelings of under-assessment by the natives as they had an opportunity to identify the losses suffered by their shrine as a result of the spillage and for the polluters, it will give a reliable estimate of the cost of re-consecrating a polluted shrine in the Niger Delta, as it frequently happens in the wake of any oil spillage.

This non-market based valuation technique is deemed appropriate since there is no established market for trading in cultural beliefs and totems of the people's traditional religion. Thus, the valuation approach replaces the market with the opinion of those affected and experts. The aim of the contingent survey is to elicit from the representatives of the community the requirements for performing the necessary rituals to appease the shrine for the desecration, the assumption being that the appeasement would attract the shrine whose home has been desecrated and re-establish its sacredness.

\section{Research Question}

The main research question was: Are socio-cultural values of good/services on contaminated land incorporated in the damage assessment process in the Niger Delta of Nigeria? 
To answer this question, a case study of an area contaminated by oil pollution in the Niger Delta was chosen for analysis. The case study was the pollution in Gokana local government of Rivers State where a series of oil spillages affected the wetland of a coastal community. The impacted land is situated within a tropical rain forest region with an annual rainfall of over $3000 \mathrm{~mm}$. The area is traversed by major and minor rivers, creeks and streams, notable amongst which is the Kolasugi-Tesoro Creek and the Bodogarara Creek. Being rainforest vegetation, the bush outside the perimeters of the impacted area is dense with mangrove forests containing economic trees such as Oil Palm, Raffia Palm and Napa Palm. The rain forest vegetation provides valuable farm land and the swamp forest provides rich fishing grounds and seasonal farming which are the main occupations of the people of Khana coastal communities.

Losses suffered by the community included contamination of fish ponds and fishing channels, contamination of the mangrove forest resulting in the loss of mangrove and other economic trees, non-timber forest resources like crabs, periwinkles, crayfish and other seafoods usually gathered freely from the mangrove vegetation, and contamination of water sources and fishing gear. The community put up claims for the desecration of 14 communal shrines, most notably Zormuu, Zor Gberebaga and Bamu Taamu. Some of the shrines are ascribed with certain functions for which they are worshipped. For example, the Zormuu Shrine is worshipped for its protective powers against enemy attack. It is believed that it affords its worshippers protection in times of trouble. The Zorkpa Shrine is ascribed with powers for the fertility of the soil and the females who farm the soil. These shrines are administered to by certain persons known as "Chief Priests" of the respective shrines. The Chief Priests are the custodians of the people's culture and intercede between the adherents and the gods. They interpret what the shrines need for appeasement and what it requires the adherents to do at what time, and generally serve as the spokespersons of the respective shrines. Some shrines have female "Priestesses" while some have male "Priests".

It is anticipated that the chief priests will provide an inventory of the sacrificial items needed and the valuer can then ascertain the cost of these items and incorporate these costs as the lost values working on the axiom that a property cannot have a value in excess of its cost of reproduction new or the price at which an equivalent and equally desirable holding can be acquired [34].

\section{Results and Discussions}

Table 1 [35] summarises the methodology adopted for this study.

Table 1. Methodology. Source: Akujuru and Ruddock [35].

\begin{tabular}{cccc}
\hline Serial No. & Strategy & Technique & Sample \\
\hline 1. & Interviews & Face-to-Face & 14 \\
2. & Questionnaire & Semi-structured & 300 \\
3. & Valuation Method & SPM-CVM & \\
\hline
\end{tabular}

The questionnaire described the shrines and sacred places as the good that was to be valued and elicited information about those that sacrifice to them, the purpose of the shrines and sacred places, frequency of sacrifice, items of sacrifice and consequences of no sacrifice. The identification of knowledgeable persons about each shrine helped identify their respective chief priests, who are the 
custodians of the tradition and practices of each shrine. Other respondents to the questionnaires were the rural dwellers whose primary occupation is fishing and farming. Each household consists of a man and his wife with children varying between 4 and 8 and consisting of both boys and girls. Children in the Niger Delta continue to live with their parents until they marry. Table 2 describes the characteristics of the respondents.

Table 2. Characteristics of respondents. Source: Akujuru and Ruddock [35].

\begin{tabular}{ccc}
\hline Occupation & Gender & Percentage \\
\hline \multirow{2}{*}{ Fishing $(40 \%)$} & Men & 55 \\
& Female & 45 \\
\hline \multirow{2}{*}{ Farming $(28 \%)$} & Men & 55 \\
Gathering (NTFPs) $(15 \%)$ & Female & 45 \\
\hline \multirow{2}{*}{ Trading $(13 \%)$} & Men & 0 \\
& Female & 100 \\
\hline \multirow{2}{*}{ Hunting $(4 \%)$} & Men & 60 \\
& Female & 40 \\
\hline
\end{tabular}

Five hundred questionnaires were distributed within the coastal community between October and December 2009. The questionnaires were served on identified heads of households in the community, identified as fisher men or farmers. A total of 300 questionnaires were returned indicating a response rate of $60 \%$. An analysis of the questionnaires indicated that $64 \%$ of the respondents felt that the values recommended by the valuers as compensation for the contamination were very inadequate. Eighteen percent felt the figures were somewhat inadequate, $12 \%$ stated that they were somewhat adequate, while $6 \%$ were neutral and none felt that the figures were adequate. The valuers did not include any compensation for the desecration of shrines. These responses confirmed the incomprehensive nature of the values returned by professional valuers, who rely on the normative property valuation models to assess compensation resulting from contamination and highlights the need to adopt a more robust approach in determining compensation due. In response to the lost income due to contamination of the environment, $80 \%$ of the respondents stated that they were earning between N550,000 and N750,000 (averaging about N650,000 per annum) before the oil spill. This contrasts with the findings of Ezebilo and Mattson [36] for Okwangwo community in Cross Rivers State where the average income from NTPF was N19,977 per annum and the findings of Akanni [21] for states in the south-west of Nigeria where a total income of N2,053,738 was reported for a combination of snails, mushrooms and teak leaves. While the Cross River State location is a remote rural neighbourhood, the south-west region is an agrarian region with a lot of commercial agriculture. The respondents reported after the spill an income of N195,000 per annum indicating a fall of $70.00 \%$ which they attributed to the effect of the contamination. When asked to state the composition of this income, about $75 \%$ of the respondents stated that $30 \%$ of their annual income is ascribed to NTFPs and $70 \%$ to fishing; this compares to $12.6 \%$ in Cross River State, $25 \%$ in the Brazillian Amazon and 28\% in Anddhra Pradesh in India, reported by Ezebilo and Mattson [36]. The respondents stated that NTFPs are mostly gathered by the women members of the community and 
that the incomes stated were total household incomes, corroborating Akanni [21], and stressed that part of the loss in income is due to the desecration of their shrines which ensured high yields in their occupation. This meant that the absence of any value due to desecration in the valuer's computation was part of the reason why the community felt the values were very inadequate.

The contingency survey of chief priests provided a list of the items needed for appeasement of the desecrated shrines. The survey revealed that the requirements differed from one shrine to the other depending on the importance and power ascribed to each shrine, but the items included assorted alcoholic drinks, mineral drinks, palm wine, native gin, yams (raw and pounded), plantains, native cows, rams, tortoise, goats, sheep, cocks and hens, and cooking ingredients. Others included uniforms for dancers, George cloth, red and white cloths, candles of different colours, incense, powder and tobacco. These items are required in different quantities depending on the assumed power of the shrine. With this list, the valuer can then determine the cost of the various quantities and derive a composite value lost due to desecration by the contamination, bearing in mind that value is created by human need and desire and that the value of a thing is its relative desirability as compared to other things (Hyder, [34]). By translating the list of items into a value, the valuer will be expressing this relative desirability in terms of money.

Contamination of a wetland involves damage to both economic and socio-cultural values which when combined with the ecological values of the environment indicate the total economic value (TEV) of the contaminated land. Aylward and Barbier [37] opined that the total economic value of an ecosystem is derived by estimating monetary values for its direct use, indirect use, option and non-use values and that the methodology for valuing such environmental goods in developing countries differ from those used in developed economies. Hence, while stated preference methods may be used in developed economies, they may be replaced by more cost effective approaches in developing countries like Nigeria. Valuers assessing damages due to contamination rely on the normative property valuation models that they have been trained to use, but such methods determine values that are considered very inadequate and do not capture the peculiarity of wetlands like the Niger Delta which contain both economic and socio-cultural values like NTFPs and cultural beliefs. NTFPs consist of naturally grown stocks of forest resources, which could be processed either for household consumption or for local and external trade by the forest users. They include a wide range of edibles and non-edibles such as fruits, seeds, leaves, nuts, bush meat, roots, tubers, fibres, resins, latex, sticks, ropes, and construction materials like bamboos and rattans and a host of others (Akanni, [21]). There are the spiritual and cultural values of NTFPs and of forest resources in general. The significance of forest resources for people's culture must not be overlooked and the uses of many resources are closely linked with people's beliefs and identity e.g., the use of the kola nut. NTFPs provide food or sources of income for their gatherers, while some are used for the domestic needs of the rural dwellers like the use of bamboo for building construction and other utility items or the regular consumption of wild meat and vegetables. Angelsen and Wunder 2003, cited by Belcher et al. [38], opined that NTFPs can be critically important to fill gaps created by agricultural shortfalls or to respond to other emergencies. Belcher et al. [37] contended that there is strong evidence that in certain conditions the poor are disproportionately dependent on NTFPs.

There is a complex interaction between social, cultural, economic, and environmental factors surrounding the execution of development projects generally. Cultural values include the traditional 
religion and beliefs of the people and may manifest as a sacred site. A sacred site is a place which is considered holy and is partially or wholly reserved for religious or ceremonial functions. Sacred shrines and groves are places where it is believed ancestors live and through which they communicate with the present generation of worshippers (Aluko et al. [39]). Traditionally, it is believed that nature/the universe is a manifestation of god or spirits and certain land or forests are held as sacred and trees designated as shrines or totems (Zografos and Kumar, [18]). De Groot et al. [14] contend that the TEV of a wetland like the Niger Delta incorporates these cultural values which need to be valued. Wilk and Cligget [40] opine that economic values are not objective facts nor do they reflect universal truths, but instead they reflect the culturally constructed realities, worldviews, mind sets and belief systems of particular societies and/or sectors of society. Shmelev [41] argued that, though the inclusion of social and cultural criteria is desirable, economic valuation is limited by the fact that it is difficult to attain as it is constrained by methodological limitations. The TEV of the Niger Delta wetland can only be determined if the socio-cultural values of the people are incorporated in a valuation exercise. As stated by Turner et al. [16], valuation studies face the challenge of recognising the inter-dependency among many types of ecosystem services and that of different interest groups competing or associated with different parts of the same ecosystem.

\section{Conclusions}

Contamination of a wetland involves damage to both economic and socio-cultural values which when combined with the ecological values of the environment indicate the total economic value (TEV) of the contaminated land. While valuers assessing damages due to contamination rely on the normative property valuation models that they have been trained to use, such methods determine values that are considered very inadequate and do not capture the peculiarity of wetlands like the Niger Delta which contain both economic and socio-cultural values like NTFPs and cultural beliefs. There is a complex interaction between social, cultural, economic, and environmental factors affecting ecosystem goods and services. Cultural values include the traditional religion and beliefs of the people and may manifest as a sacred site. A sacred site is a place which is considered holy and is partially or wholly reserved for religious or ceremonial functions. Adopting a valuation approach that reflects the value of cultural goods like shrines and totems will assuage the feelings of the host communities that they are deprived by the oil and gas companies of their rights when offered any compensation. This will minimise their hostility to the operations of such companies and their reluctance to accept any compensation offered as a result of damages due to contamination. Practicing valuers will be more confident that they have duly reflected the opinions of their clients in their valuations and fully captured the value determinants in the process of their value determination. By paying compensation that embodies socio-cultural values, the oil and gas companies will be purchasing an operational license, since this will assist in providing an enabling environment for their operations and minimise their perceived high-handedness in dealing with their host communities. It will also erase the notion that compensations are predetermined without a consideration of actual damages suffered. While the contingency survey method may have its shortcomings, it offers the best opportunity to capture the cultural values lost due to contamination. By consulting the Chief Priests, valuers can use valuation as a useful tool for assessing the diminution 
in value of the shrines and totems as they are perceived by the worshippers whose views have been ignored in the past.

\section{Author Contributions}

Main text of the paper authored by Victor A. Akujuru and Les Ruddock. Reviewers' comments were also responded to by both authors.

\section{Conflicts of Interest}

The authors declare no conflict of interest.

\section{Appendix}

\section{Valuation Framework}

Being a wetland and assuming a developed property is standing on it, the damage due to contamination can be established from the formula:

$$
\left(\mathrm{V}_{\mathrm{o}}+\mathrm{V}_{\mathrm{p}}+\mathrm{V}_{\mathrm{d}}\right)
$$

where $V_{o}$ is Damage due to Contamination; $V_{d}=$ Diminution in Value, and $V_{p}=$ Value of the Contaminated Property, and

$$
\mathrm{V}_{\mathrm{p}}=\left(\mathrm{R}_{\mathrm{c}}+\mathrm{I}_{\mathrm{c}}+\mathrm{L}_{\mathrm{c}}+\mathrm{CU}_{\mathrm{c}}+\mathrm{Y}_{\mathrm{c}}\right)
$$

where

$\mathrm{R}_{\mathrm{c}}=$ Income and revenue losses from use and occupation of the wetland;

$I_{c}=$ Costs of scientific investigations to determine extent and impact of contamination;

$\mathrm{L}_{\mathrm{c}}=$ Legal costs where agreed in advance;

$\mathrm{CU}_{\mathrm{c}}=$ Clean-up costs to prepare for subsequent use;

$\mathrm{Y}_{\mathrm{c}}=$ Any other incidental costs not captured above, and

$\mathrm{V}_{\mathrm{d}}=\mathrm{V}_{\mathrm{u}}-\left(\mathrm{I}_{\mathrm{c}}+\mathrm{R}_{\mathrm{i}}+\mathrm{M}_{\mathrm{r}}\right)$.

where

$\mathrm{V}_{\mathrm{u}}=$ Value of Property unimpaired;

$\mathrm{I}_{\mathrm{c}}=$ as above;

$\mathrm{R}_{\mathrm{i}}=$ Repair costs to the property;

$\mathrm{M}_{\mathrm{r}}=$ Risk associated with market resistance to contamination determined by the discount in price paid for similar properties by purchasers.

The above framework captures the peculiarities of a wetland and will reflect heads of claim that meet international best practices and minimise the conflicts that attend dissatisfaction with the current compensation regimes. 


\section{References}

1. Whipple, R.T.M. Property Valuation and Analysis; Law Book: Sydney, NSW, Australia, 1995.

2. Estate Surveyors and Valuers Registration Board. Cap E. 13, LFN. Estate Surveyors and Valuers (Registration, etc.) Act of 1975; Government Printing Press: Abuja, Nigeria, 2007.

3. Redford, K.H. The many values of wild animals in forest ecosystems. In Current Issues in Non-Timber Forest Products Research; Centre for International Forestry Research: Hotspring, Zimbabwe, 1995; pp. 41-53.

4. Niger Delta Development Commission (NDDC). Niger Delta Regional Development Master Plan; Office of The Secretary to The Federal Government, Ed.; South-Sea Datcomm Limited: Abuja, Nigeria, 2006.

5. National Space Research and Development Agency (NASRDA). Political Map of the Niger Delta Region of Nigeria; NASRDA: Abuja, Nigeria, 2008.

6. Central Inteligence Agency ( CIA). World Factbook; The United States Central Intelligence Agency: Langley, VA, USA, 2013.

7. Nwilo, P.C.; Badejo, O.T. Impacts of Oil Spill Pollution Along the Nigerian Coastal Areas; International Federation of Surveyors: Paris, France, 2007.

8. Nigerian National Petroleum Corporation (NNPC), Ed. Department of Petroleum Resources Publications; NNPC: Abuja, Nigeria, 2010.

9. Nigerian National Petroleum Corporation (NNPC). Pipeline, Oil Spill Prevention and Remediation in Niger Delta Area; NNPC Publications: Abuja, Nigeria, 2007.

10. Babawale, G.K. Emerging issues in compensation valuation for oil spillage in the Niger Delta area of Nigeria. J. Rev. Glob. Econ. 2013, 2, 31-45.

11. Cap L5, L.F.N. 2004. Land Use Act 1978; Federal Government of Nigeria: Abuja, Nigeria, 2004; p. 24.

12. Uchendu, V.C. State, land, and society in Nigeria: A critical assessment of land use decree (1978). J. Afr. Stud. 1979, 6, 62-74.

13. Rosa, H.; Barry, D.; Kandel, S.; Dimas, L. Compensation for Environmental Services and Rural Communities: Lessons from the Americas, Proceedings of the International Conference on Natural Assets, Tagaytay City, Philippines, 8-11 January 2003; Political Economy Research Institute, University of Massachusetts: Amherst, MA, USA, 2004.

14. De Groot, R.S.; Wilson, M.A.; Boumans, R.M.J. A typology for the classification, description and valuation of ecosystem functions, goods and services. Ecol. Econ. 2002, 4, 393-408.

15. Curtis, I.A. Valuing ecosystem goods and services: A new approach using a surrogate market and the combination of a multiple criteria analysis and a Delphi panel to assign weights to attributes. Ecol. Econ. 2004, 50, 163-194.

16. Turner, R.K.; Morse-Jones, S.; Fisher, B. Ecosystem valuation: A sequential decision support system and quality assessment issues. Ann. NY Acad. Sci. 2010, 1185, 79-101.

17. Millennium Ecosystem Assessment (MA). Ecosystems and Human Well-Being: Wetlands and Water (Synthesis)—A Report of the Millennium Ecosystem; World Resources Institute: Washington, DC, USA, 2005; p. 67. 
18. Zografos, C.; Kumar, M. Socio-cultural context of ecosystem and biodiversity valuation. In The Economics of Ecosystems and Biodiversity: The Ecological and Economic Foundations; Martinez-Alier, J., Ed.; The Economics of Ecosystem and Biodiversity (TEEB), United Nations Environment Programme (UNEP): Geneva, Switzerland, 2010; pp. 1-39.

19. Yagha, S.S. Cinnamon and cemetries: The valuation of exotics. In Valuation 2000; Appraisal Institute: Chicago, IL, USA, 2000; pp. 261-273.

20. Food and Agriculture Organization (FAO). The major significanceof minor forest products. In The Local Use and Value of Forest in West African Humid Zone; Community Forest: Rome, Italy, 1990; p. 242.

21. Akanni, K. Economic benefits of non-timber forest products among rural communities in Nigeria. Environ. Nat. Resour. Res. 2013, 3, doi:10.5539/enrr.v3n4p19.

22. Sullivan, C. Then economic and social value of non-timber forest products in a forest village economy in N.W. Guyana. In Tronpenbos-Guyana Programme Reports; Keele University: Newcastle-under-Lyme, UK, 1997; pp. 1-82.

23. Hoare, A.L. The Use of Non-Timber Forest Products in the Congo Basin: Constraints and Opportunities; Rainforest Foundation: London, UK, 2007.

24. Clark, L.E.; Sunderland, T.C.H. Building knowledge of the non-timber forest product sector in central Africa. In The Key Non-Timber Forest Products of Central Africa: State of the Knowledge; Central African Regional Program for the Environment (CARPE), Ed.; United States Agency for International Development (USAID): Washington, DC, USA, 2004; pp. 1-10.

25. Vecco, M. A definition of cultural heritage: From the tangible to the intangible. J. Cult. Herit. 2010, 11, 321-324.

26. Ogunba, O.A.; Adegunle, T.O. Cultural heritage valuation in african commonwealth countries: An examination of conceptual and methodological issues. In Proceedings of the African Real Estate Society (AfRES) Annual Conference, Kigali, Rwanda, 23-26 October, 2013; p. 19.

27. International Valuations Standards Committee (IVSC). International Valuation Standards; IVSC: London, UK, 2007; p. 462.

28. Defrancesco, E.; Gatto, P.; Rosato, P.; Bozzolan, I. The environmental damage compensation: An integrated framework. Rivista SIEV, September 2012, pp. 1-12.

29. World Bank. Economic analysis and environmental assessment. In Environmental Assessment Source Book Update; World Bank: Washington, DC, USA,1998; pp. 1-14.

30. Department of Transport and Local Government Regions (DLTR). Economic Valuation with Stated Preference Technique, Summary Guide; Department of Transport, Ed.; Her Majesty Stationery Office (HMSO): London, UK, 2002.

31. Glaves, P.; Egan, D. Some Methods and Approached to Valuing Ecosystem Services. 2013; Available online: http:/www.cieem.net/data/files/Resource_Library/Conferences/ 2013_Spring_Ecosystem_Services/Methods_for_Valuing_Ecosystem_Services.pdf (accessed on 4 February 2014).

32. Lusvardi, W.C. Valuing nature land in extinct markets. Apprais. J. 1999, 7, 293-305.

33. Matthew, E.K. Under the microscope: Dissection of a contingent valuation survey. Apprais. J. 2008, 76, 259-269.

34. Hyder, L.K. The appraisal process. Apprais. J. 2007, 75(3), 227-232. 
35. Akujuru, V.A.; Ruddock, L. (University of Salford, Salford, UK). Unpublished questionnaire survey of polluted wetlands in the Niger Delta region of Nigeria, 2013.

36. Ezebilo, E.E.; Mattson, L. Contribution of non-timber forest products to livelihoods of communities in Southeast Nigeria. Int. J. Sustain. Dev. World Ecol. 2010, 17, 231-235.

37. Aylward, B.; Barbier, E.B. Valuing environmental functions in developing countries. Biodivers. Conserv. 1992, 1, 34-50.

38. Belcher, K.; Schreckenberg, K. Commercialisation of non-timber forest products: A reality check. Dev. Policy Rev. 2007, 25, 355-377.

39. Aluko, B.T.; Omisore, E.O.; Amidu, A.R. Valuation of yoruba sacred shrines, monuments and groves for compensation. In Indegenous People and Real Estate Valuation; Simon, R.A, Malmgren, M.R., Small, G., Eds.; Springer Science and Media: Houten, The Netherlands, 2008; pp. $145-173$.

40. Wilk, R.R.; Cliggett, L.C. Economics and the problem of human nature. In Economies and Cultures: Foundations of Economic Anthropology; Westview Press: Boulder, CO, USA, 2007; pp. 31-47.

41. Shmelev, S.E. The economic system and the environment. In Ecological Economics; Springer: London, UK, 2012; pp. 3-16.

(C) 2014 by the authors; licensee MDPI, Basel, Switzerland. This article is an open access article distributed under the terms and conditions of the Creative Commons Attribution license (http://creativecommons.org/licenses/by/3.0/). 